\title{
AGAINST EQUALITY
}

Readings on Economic and Social Policy 
The compilation and publication of this set of readings has been assisted by a grant from the Foundation for Education in Economics, whose Trustees are: Professor Julius Gould, Professor Jack Wiseman and Simon Webley 


\section{AGAINST \\ EQUALITY}

Readings on Economic and Social Policy

$\neq$

Edited by

WILLIAM LETWIN

The Macmillan Education in association with the

Foundation for Education in Economics

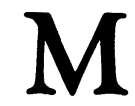


Selection, editorial matter, introductory chapter 'The Case Against Equality' and concluding chapter 'The Grail of Equality' (c) Foundation for Education in Economics 1983

All rights reserved. No part of this publication may be reproduced or transmitted, in any form or by any means, without permission.

First published 1983 by

THE MACMILLAN PRESS LTD

London and Basingstoke

Companies and representatives throughout the world

ISBN 978-0-333-35313-4 ISBN 978-1-349-17175-0 (eBook)

DOI 10.1007/978-1-349-17175-0

Typeset by

WESSEX TYPESETTERS LTD

Frome, Somerset 


\section{Contents}

List of Contributors

vii

Editor's Preface ix

1 The Case Against Equality

WILLIAM LETWIN (1983)

PART ONE: EGALITARIANISM, ITS

THEORETICAL WEAKNESSES

2 Against Equality Again

J. R. LUCAS (1977)

3 The Idea of Equality as a Substantive Principle of Society

$\begin{array}{lll}\text { JOHN CHARVET (1969) } & 106\end{array}$

4 The Pursuit of Equality

ROBERT NISBET (1974) 124

5 The Procrustean Ideal

ANTONY FLEW (1978)

PART TWO: EQUALITY OF OPPORTUNITY AND

EQUALITY BEFORE THE LAW

6 Equality of Opportunity

CHARLES FRANKEL (1971)

7 Equality of Opportunity and Equality of

Results

JAMES S. COLEMAN (1973)

8 The Idea of Equality Reconsidered

ANDREW WARD (1973)

9 Equality Under the Law

GEOFFREY MARSHALL (1971) 
vi CONTENTS

PART THREE: ECONOMIC INEQUALITY, ITS EXTENT AND CAUSES

10 How Unevenly Is Wealth Spread Today?

GEORGE POLANYI \& JOHN B. WOOD (1974)

11 The Stability of Inequality

KENNETH E. BOULDING (1975)

12 Equality and Economic Theory

HARRY G. JOHNSON (1975)

PART FOUR: REDISTRIBUTION, ITS AILMENTS

13 The Egalitarian Imperative RICHARD E. WAGNER (1977)

14 Can Inequality Be Cured?

NATHAN KEYFITZ (1973)

15 The Charity of the Uncharitable GORDON TULLOCK (1971)

16 Economic Justice and the Economist RICHARD A. POSNER (1973)

17 The Grail of Equality

PETER BAUER (1983)

Notes and References

383

Index of Names

Index of Subjects 


\section{List of contributors}

PETER BAUER: Professor of Economics, London School of Economics and Political Science; sometime Fellow of Caius College, Cambridge.

Kenneth E. Boulding: White Professor at Large, Cornell University.

JOHN Charvet: Reader in Political Science, London School of Economics.

JAMES S. COLEMAN: Professor of Sociology, University of Chicago.

ANTONY FLEW: Professor of Philosophy, University of Reading.

THE LATE Charles Frankel: Former President, National Humanities Center, Columbia University.

THE LATE HARRY G. JOHNSON: Former Charles F. Grey Distinguished Service Professor, University of Chicago; former Professor of Economics, London School of Economics.

NATHAN Keyfitz: Andelot Professor of Sociology and Demography, Harvard University.

William LetWin:- Professor of Political Science, London School of Economics.

J. R. LUCAS: Fellow of Merton College, Oxford. 
GeOfFrey MARShall: Fellow of The Queen's College, Oxford.

ROBERT NiSBET: Resident Scholar, American Enterprise Institute, Washington, DC.

THE LATE GEORge POLANYI: Former Research Officer, Institute of Economic Affairs, London.

RICHARD A. POSNER: Professor of Law, University of Chicago.

GORDON TULLOCK: University Distinguished Professor of Economics and Public Choice, Virginia Polytechnic Institute and State University.

RiChARD E. WAGNER: Professor of Economics, Virginia Polytechnic Institute and State University.

ANDREW WARD: Sometime Senior Member, Fitzwilliam College, Cambridge.

JOHN B. WOOD: Deputy Director, Institute of Economic Affairs, London. 


\section{Editor's preface}

I have designed this book to challenge and to rebut egalitarianism. My own view of the matter is set out in the introductory essay. I selected the other essays because they illuminate certain issues that arise in scrutinising the egalitarian position. But I should emphasise that the inclusion of an essay in this collection is not to be interpreted as a sign that the author shares either my general opposition to egalitarianism (though many of the authors evidently do) or my particular views on any of the more specific questions which they and I discuss. In short, the essays collected here do not hew to any orthodoxy.

Although the essays are grouped in accordance with certain main topics, most of them are not narrowly confined to one of those topics but bear also on the broader issue.

The question of 'social equality' - which concerns differences of status, class, esteem and the like - receives less attention here than other aspects of equality. Reasons are suggested, nevertheless, for concluding that the claims of egalitarianism in the social sphere are as baseless as in any other and that the prospects for equalisation are more hopeless than elsewhere.

I should like to thank for their help in producing this volume the Foundation for Education in Economics, and particularly Professor Julius Gould and Mr Simon Webley.

My grateful acknowledgement is due to the authors and original publishers of the selected essays for permission to reproduce them here. The source is given at the foot of the opening page of each chapter. The variant usages of British and American English have been retained as in the original printings.

W.L. 